\title{
THE PROMOTION IMPLEMENTATION OF THE CULTURE AND TOURISM DEPARTMENT OF INDONESIA ON THE OPEN PIT NAM SALU GEOSIT TOURISM OBJECT
}

\author{
Desayu Eka Surya \\ Department of Communication Science, Universitas Komputer Indonesia, Bandung, Indonesia \\ Beni Efrianto \\ Department of Communication Science, Universitas Komputer Indonesia, Bandung, Indonesia
}

\begin{abstract}
The purpose of the study was to determine the implementation of the promotion of the Department of Culture and Tourism of East Belitung Regency at the Open Pit Nam Salu Geosit tourist attraction. The research was conducted with a qualitative approach, using descriptive methods, data collection techniques using literature review, and field studies consisting of observations, interviews, and documentation. The results showed that various promotions had been carried out by the Department of Culture and Tourism of East Belitung Regency to increase tourist visits to the Open Pit Nam Salu Geosit tourist attraction through advertisements, online media, and print media. The officers also carry out promotions through personal selling to promote Open Pit Nam Salu Geosit, namely through Whatsapp broadcasting, exhibitions, and tabletop events. Other promotional activities include sales promotions by launching tour package events in collaboration with the Communication and Informatics Office, Education Office, Industry and Trade Cooperative Office in charge of Small and Medium Enterprises (SMEs) in East Belitung Regency, as well as local and national media. The promotion was carried out because the target public of the Open Pit Nam Salu Geosit tourist attraction varied from social, economic, and age backgrounds. The promotion's impact and usefulness are that more and more people know about the Open Pit Nam Salu Geosit tourist attraction, so they are interested in visiting it, making the tourist attraction more popular. Research advice is to pay attention to places that sell billboards. For example, by placing them in the middle of the city that the public easily sees them.
\end{abstract}

Keywords: Promotion, Culture, Tourism

DOI: http://dx.doi.org/10.15549/jeecar.v9i1.871

\section{INTRODUCTION}

The ability to carry out promotions is an important part of the organization, especially to promote new products to be marketed to the public. The promotional activity studied was the promotion of the East Belitung Regency Culture and Tourism Office at the Open Pit Nam Salu Geosit tourist attraction. Open Pit Nam Salu Geosit Tourism Object was previously a Dutch tin mining site. The Dutch did tin mining by digging holes in the ground to form a hollow hole that resembles a crater, and now the hole has turned 
into a beautiful green lake, and there is an underground tunnel.

Carrying out promotions in the world of tourism is important because not all people around the tourist attraction, especially the public or tourists from outside the region and even foreign countries, will not know it without promotion through various media. By doing the proper promotion, the tourist attraction will be known and visited by many people, which will add financial-economic input for tourism managers in their respective areas, in this study, namely the East Belitung Tourism and Culture Office. Tourism is a creative industry sector that is currently experiencing development. Tourism can be used as the exact alternative to release boredom by individuals and groups. A tourist attraction triggers a person and or a group of people to visit a place for its particular meaning, such as the natural environment, heritage or historical sites, and certain events (Aliyah, 2017).

Even though it is not a new problem, the research about tourism communication is still interesting to observe and analyze, as well as the title of this research on the implementation of the promotion carried out as the cultural promotion tool by the Culture and Tourism Department of East Belitung Regency on the Open Pit Nam Salu Geosit tourism objects. This effort is needed to help the development of tourism in Belitung Regency to attract tourists to visit this area. The number of visitors who come to the Open Pit Nam Salu Geosit tourist attraction can certainly benefit the community and the government of East Belitung Regency. It is undeniable that the tourism sector can bring a massive income for the region if it is managed seriously. Therefore, the researchers conclude the points above as the crucial reason highlighted by the titles of this research.

Basiya, Abdul and Rozak stated that tourist attraction is the first motivation for visitors to make tourist visits, tourist attractions are classified into several attractions including (a) Natural attractions consisting of natural scenery both land, ocean, beach, and climate or weather, (b) architectural tourist attraction (building attraction) which includes historic buildings and architecture, modern buildings and architecture, and archeology, (c) managed visitor attractions, (d) cultural attractions which include theaters, museums, historical places, culturalism, religious places, special events. (Basiya, Abdul \& Rozak, 2012).

Sourced from the (Ajeng Fitri N, 2016) research, it shows that tourist attraction has a significant effect on tourist satisfaction and a significant direct influence on the tourists' intention to revisit (Fitri, 2016). Meanwhile, (Yolanda, 2017) research shows that tourist attraction influences the visiting decision variable by $54.5 \%$. In comparison, research (Diniyah, 2019) shows that tourist attraction has greatly influenced the tourists' intention to revisit the Vredebug museum in Yogyakarta.

Promotion of Indonesian culture and cultural promotion carried out by the Culture and Tourism Department of Belitung Regency at the Open Pit Nam Salu Geosit Tourism Object should be done to help the development of tourism in Belitung Regency, which can attract tourists to visit this area. The number of visitors who come to the Open Pit Nam Salu Geosit tourist attraction can certainly benefit the community and the East Belitung Regency government. It is undeniable that the tourism sector can bring a high income to the region if it is thoughtfully managed.

As written by I Dewa Ayu Hendrawathy in his article published by the Journal of Communication Studies, Dwijendra University, Bali, Indonesia, we are well aware that this nation's success will depend on this nation's development rests on us and not on others. Competition between nations is becoming more demanding. In this case, the determining factor that will be able to answer is the quality of human resources (Manpower) at various layers and various sectors, both private and government. However, tourism has become a mainstay sector that is expected to be a "Prime Mover" in national economic development, so that strategic steps are needed for its growth in the Asia Pacific (Diniyah, 2019).

Wahab (1985) in Yoety explained that tourism is one of the new types of industries that can create rapid economic development in providing employment, increasing income, living standards, and stimulating other productivity sectors. Tourism also includes classic industries such as souvenirs, accommodation, and economical transportation are also viewed as industries (Yoety, 2006).

Komang Tri Werthi, said: "Indonesian culture is a legacy from ancestors that must be protected and preserved from generation to generation" 
(Wartaeven, 2021). Komang asked, if it is not the nation's children who preserve their own culture, then who else? Moreover, considering the variety of cultures of Indonesia, it can strengthen the roots of national identity. He continued, hunting for cultural knowledge through social media was not enough. There needs to be further understanding through reading literature from history books. "In addition, discussions about the Indonesian culture history are also very helpful in introducing Indonesian culture to other countries (Werthi, 2021).

Information from Putu Sujana's article published by the Tourism Analysis Journal, Udayana University, Bali, Indonesia, stated that to be able to increase the participation of the nation's youth as a society, it is necessary to develop development programs or innovations that are developed containing the following elements:

1. Provide relative benefits, economically affordable and it is considered that the costs incurred are smaller than the results obtained (relative advantage);

2. The elements of innovation are deemed not to conflict with local values and beliefs (compatibility);

3. New ideas and new practices that are communicated can be easily understood and practiced (complexity and practicability); and

4. Elements of the innovation are easy to observe through demonstrations or demonstrations (observability). (10)

Some of the most important factors in promotional activity are to design a good message and the selection of effective and efficient media. In addition, we must calculate the context that is conveyed to the target audience to get the desired response. Tjiptono defines promotion as several activities designed to communicate a product to consumers to provide information of a product's usefulness, and from its features and existence to change attitudes or to encourage people to act (Sudana, 2013). The promotion implementation is an important matter for every organization as well as for the Culture and Tourism Department of East Belitung Regency.

However, although various studies on promoting culture and tourism have been carried out, the researcher considers that researching on the promotions of historical relics that have been abandoned and forgotten for a long time preserved and promoted through various publications, including mass dan social media.

Based on the description above, the researcher understands that implementing promotions is an important part of an organization. Especially, in promoting new products that need to be conveyed to the public, the Department of Culture and Tourism Department of East Belitung Regency, needs to play an essential role in the attraction of tourists to visit the Open Pit Nam Salu Geosit. As stated by Iphan Oktoriadi as a research informant during initial field observations, he said, "Implementing promotions is very important, because if you don't do promotions, people don't understand and don't know about good tourist objects in this area. Thus, the attractions in The Belitung Regency area will be deserted for there are no visitors. Therefore, the Tourism Department must promote it to the community, both local and foreign people". (Tjipno, 2008). To explore the beauty of the Open Pit Nam Salu Geosit, we can access it by motorbike or do it by hiking accompanied by a local guide.

Here is one side of the Open Pit Nam Salu Geosit attraction in Figure 1.

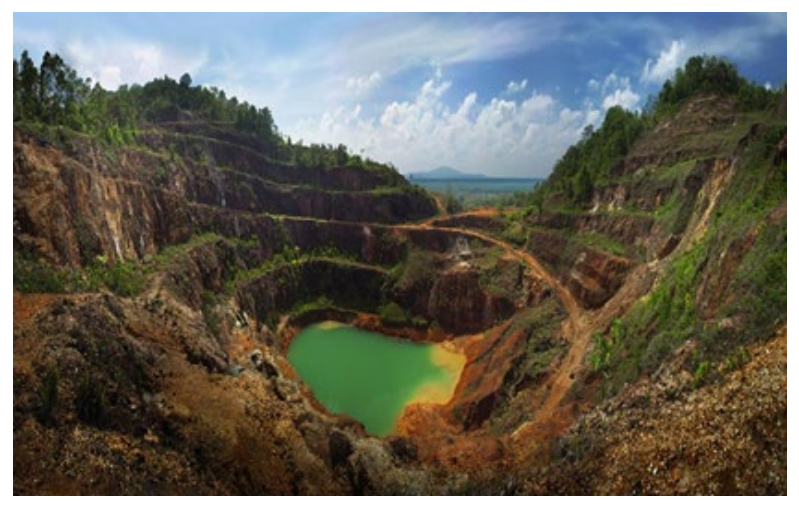

Figure 1: Open Pit Nam Salu Geosit Attraction Source: Official Site of The Culture and Tourism Department of East Belitung Regency

However, not all organizations, including the Department of Tourism and Culture, consider it important to carry out promotions about new products or new information about touristic destinations. There are still many tourist objects in their area that actually have to sell points to be visited by the public, tourist objects worth 
visiting and can entertain the public for refreshing or reminiscing about history that can increase regional economic income. In addition, many organizations have not assessed the importance of preparing Human Resources or employees who have expertise in the field of promotion. In fact, with the availability of employees who have the ability and expertise in communication, especially in advertising, it will help the East Belitung Tourism and Culture Office publish various tourist objects in the East Belitung area. This will help in becoming known to many local people and tourists from abroad.

The Culture and Tourism Department of East Belitung Regency needs to do promotions because although it has beauty and high historical value, many people have never visited, and even they do not know about the Open Pit Nam Salu Geosit attraction.

Based on the explanation of the problem background, the research aims to describe and analyze how the advertising form, personal selling, and public relations activities by the Culture and Tourism Department of East Belitung Regency.

Based on the explanation of the problem background above, this research aims to find out and analyze, 1) How is the form of advertising carried out by the Culture and Tourism Department of East Belitung Regency in promoting the Open Pit Nam Salu Geosit Tourism Object to the public, 2) What are the Forms of Personal Selling carried out by the Culture and Tourism Department of East Belitung Regency in promoting the Open Pit Nam Salu Geosit Tourism Object to the public, and 3) What are the Forms of Public Relations Activities carried out by the Culture and Tourism Department of East Belitung Regency in promoting the Open Pit Nam Salu Geosit Tourism Object to the public.

The novelties of this research are: 1) The implementation of the promotion carried out is a tourist attraction that previously came from the Tin Mining and was not a tourist object from the start. 2) Promotion carried out is a collaboration between conventional Promotion and Digital Promotion. It is because the people of East Belitung are not all technologically literate. Thus, conventional word of mouth is considered more effective. 3) Researching the promotion of tin mining history in the Nam Salu Geosite Open Area to Attract tourists to visit, which has never been done before.

\section{METHODOLOGY}

The research was conducted using a qualitative approach with a descriptive method. Qualitative research is a research method used to examine the condition of objects naturally, where the researcher is the key instrument. The data collection technique is done by triangulation (combined), the data analysis is inductive, and the results of qualitative research emphasize meaning rather than generalization (Sugiyono, 2017).

According to Ardianto, the descriptive method focuses on observing natural settings. The researcher went directly to the field, acting as a reviewer, and made observations without manipulating the data (Ardianto, 2010).

Research informants were selected using a purposive sampling technique, namely a sampling technique using certain considerations (Oktoriady, 2021), so that 2 key informants and 3 supporting informants were selected. The field research was carried out for one month, from June 2 to July 3,2020, by observing the location of tourist attractions and interviews with key informants and supporting informants who had been determined according to the researcher's needs. Interviews with key informants were conducted at the Office of Culture and Tourism. Meanwhile, interviews with supporting informants were conducted at the location of the How Forms of Personal Selling object conducted by the Culture and Tourism Office of East Belitung Regency in promoting the Open Pit Nam Salu Geosit Tourism Object to the public.

The data collection technique used in this research is to conduct literature studies such as book references, scientific papers, and online data searches. In contrast, field studies are conducted by interview and non-participant observation. Test the validity of the researchers' data is a discussion of friends and member check. The data obtained were analyzed using data collection techniques, data reduction, presentation, and classification.

\section{RESULTS}

Advertising of the Culture and Tourism Department of East Belitung Regency at the Open Pit Nam Salu Geosit Tourism Object

According to Eviliah and Iphan Oktoriady, advertisements by the Culture and Tourism Department of East Belitung Regency on the 
Open Pit Nam Salu Geosit Tourism Object use online media such as Facebook and Instagram Youtube, and advertising websites are also carried out through printed media such as magazines. Research informants admit that the use of social media is active, almost every week tourism objects are chosen to post on social media they manage, especially through the website promotion.

The social media used by the Culture and Tourism Department of East Belitung Regency to promote various tourist attractions in East Belitung including the Open Pit Nam Salu Geosit Tourism Object are Instagram, Facebook, Youtube, and Website. The name of the Instagram used is @ Inspiring Belitungtimur, for Facebook it is @ East East (Inspiring Belitung Timur), youtube @Inspiring Belitung Timur 2020 while the website is https: //disbudpar.belitungtimurkab.go.id. (Oktoriady, 2021).

Besides, the advertising by the Tourism Department of East Belitung Regency regarding the Open Pit Nam Salu Geosit tourist attraction uses printed media, namely magazines. The magazines used for promotion consisted of two magazines. The first magazines are managed by the Culture and Tourism Department of East Belitung Regency itself, and the second one is the national magazines.

The magazine which is managed by the Culture and Tourism Department of East Belitung Regency, is the Visit Beltim magazine. This magazine is given to guests from the government or from tourists who visit the Culture and Tourism Department of East Belitung Regency. Besides, it is also distributed at airport outlets for tourists. The Visit Beltim magazine was also given to the community when the Culture and Tourism Department of East Belitung Regency conducted counseling to villages to let people know the history and wealth of tourism values in their area. Not all people knew the background of the Open Pit Nam Salu Geosit tourist attraction. The Visit Beltim magazine contains all the tourist destinations in East Belitung regency, including the Open Pit Nam Salu Gesoit Tourism Object. The magazine includes a map of tourist and travel objects to visit the Open Pit Nam Salu Geosit Tourism Object.

The Culture and Tourism Department of East Belitung Regency cooperates with a magazine from West Java, namely the Nusae Magazine, for their national magazine. The Culture and Tourism Department of East Belitung Regency magazine tells about the Open Pit Nam Salu Gesoit tourist attraction and the various tour packages available. In addition to the Nusae Magazine, in 2019, the Culture and Tourism Department of East Belitung Regency collaborated with the airline's magazine called the in Flight magazine. In the Flight magazine, the destinations appointed by the Culture and Tourism Department of East Belitung Regency are the Open Pit Nam Salu Geosit and three other destinations: The Tebat Rasau tourist attraction Burung Mandi Beach and the Rainbow Troops Museum. The highlight of this magazine is the Open Pit Nam Salu Geosit destination (Evilliah,2021).

Personal selling of the Culture and Tourism Department of East Belitung Regency at the Open Pit Nam Salu Geosit Tourism Object

The research informant is Evilliah, Personal selling by the East Belitung Regency Tourism Department at the Open Pit Nam Salu Geosit tourist attraction using WhatsApp Broadcasting, Exhibitions, and Table Top Events. According to informants, personal selling is an initial promotional action by the East Belitung Regency Culture and Tourism Department regarding the Open Pit Nam Salu Geosit. Broadcasting is done through WhatsApp first before doing personal selling, starting with disseminating information to the closest people first such as family, friends, work partners. Besides, the Open Pit Nam Salu Geosit tourist attraction is included in the exhibition as a tourism object that is ready to be promoted with all aspects from resources to facilities. (Oktoriady, 2021).

In line with Evilliah, Iphan Oktoriady stated that only the tourist object that is ready in all aspects, both the resources and the facilities could include in the exhibition, and not all of them can join.

Sales Promotion of the Culture and Tourism Department of East Belitung Regency at the Open Pit Nam Salu Geosit Tourism Object

The sales promotion done by the Culture and Tourism Department of East Belitung Regency at the Open Pit Nam Salu Geosit Tourism Object is a Tour Package Launching. It is expected to be a variety of interesting choices for tourists, not 
only exploring Open Pit Nam Salu Geosit, 3 other package options from Open Pit Nam Salu Geosit are available such as Nindo Nam Salu, Menggemak, and Nepes. These three package options have different prices. This is the same with Eviliah statement in the interview process by the researcher with research informants as follows:

"The Culture and Tourism Department of East Belitung Regency has three package options for the Open Pit Nam Salu Geosit attraction. The first package is Nindo Nam Salu at Rp. 85,000/person for domestic tourists and Rp. 100,000/person for foreign tourists, the Nindo package Namsalu consists of the Nam Salu Open Pit Geosite Exploration, seeing Trigona honey cattle, and Biodiversity Explorer. The second package is Menggemak, this package price is Rp. $10,000 /$ person for children and Rp. 20.000/pax for adults consists of exploring the geological information center and watching a film about the history of Open Pit Nam Salu Geosit on Belitung Island. Lastly, the third package is the Nepes package for Rp. 85.000/pax (min 4 pax). This package consists of Explorer Tower Stoven, Watching the Process of Styling the Lead Sand (ngelimbang), eating the traditional Bedulang of Belitong in the traditional hall, and bergambus (traditional dancing)" (Evilliah,2021).

Sales promotion is a one-way flow of information or persuasion that can lead an organization or person to create a transaction between a buyer and a seller. Promotion is the last activity of the marketing mix that is very important for now the buyer's market is booming with the final decision on buying and selling transactions is influenced by consumers. Therefore, the buyer is king. Manufacturers of various goods compete to attract buyers interested and willing to buy their goods.

Public Relation of the Culture and Tourism Department of East Belitung Regency at the Open Pit Nam Salu Geosit Tourism Object

Public relations are done by the Culture and Tourism Department of East Belitung Regency at the Open Pit Nam Salu Geosit Tourism Object collaborates with the Public Relations office of East Belitung Regency, Diskominfo, the Coop Trade Industry Department which manages
MSMEs in East Belitung Regency, Cooperation has existed if an event related to the promotion of the Open Pit Nam Salu Geosit tourist attraction. In addition, the Culture Department and East Belitung Regency invited local media to national media to cover the event, as stated by Iphan Oktoriady when the field research was carried out as follows:

"The Culture and Tourism Department of East Belitung Regency in promotional events for tourism objects including the Open Pit Nam Salu Geosit Tourism Object always cooperates with the Communication and Information Department (Diskominfo). They help disseminate information to the public about the ongoing events when working with Diskominfo. Other departments also participated, as did the local and national mass media. National media such as INews specifically for big events such as the tour packages launching, while local media attended Pos Belitung JabeJabe and Belitung Express. (Evilliah,2021).

Activities in the field of Public Relations are a strategic function in management that communicates to produce understanding and acceptance from the public. In the process of public acceptance, companies or institutions, in this case, is the Culture and Tourism Department, need to pay attention to harmonious relations with the community. Thus, the various promotions can get the attention and support of the public as the public target.

Tourism, reporting to Yogyakarta kompas.com, tourism is a temporary journey from one place to another by an individual or in groups, as an effort to find balance or harmony and happiness with the environment in the social, cultural, natural, and scientific dimensions. (Spilane, 1987). According to Sujali (1989), the emphasis on geography is based on a spatial approach through elements such as location, area, shape, boundaries, and distribution. Tourism can bring many benefits to society economically, socially, and culturally. Alistair Speirs, Chairman of Superbands, at the Heritage Tourism discussion in Yogyakarta on December 17, 2010, revealed that tourism is the industry that provides the most significant income with rank one or two in several countries in the world.

Moreover, Speirs said that the current trend is cultural heritage tourism. Tourists are not just sightseeing but want to see the local culture and 
lifestyle. People who seek culture spend more money than people who just travel. Indonesia is rich in heritage sites, therefore it has great potential to develop heritage tourism. Indonesia has many interesting objects for world tourists and is also a country with the most UNESCOrecognized heritage sites in Southeast Asia. (Speirs, 2010).

Many domestic and overseas tourists come to various regions in Indonesia to learn about the various cultures that exist in Indonesia.

\section{Communication and Tourism}

Tourism and communication have a reciprocal relationship. Both tourism and communication affect each other. Explaining or analyzing the relationship between these two elements becomes more complicated. Tourism can affect the process of how a person perceives reality. All communities in all places always manifest or realize their view of reality through tourism objects. On the other hand, communication helps us create the reality of tourism objects from a community.

\section{Tourism affects Communication.}

The reciprocal relationship between tourism and communication is vital in studying tourism communication. This happens because people can learn to communicate through tourist objects.

Through the historical heritage of a tourist object, from perception, it is possible to have meant that similar to a particular social reality or event. As we know, it can naturally affect our perspective and practice of communicating as we have visited different tourist objects. Thus, many aspects/elements of tourism can affect a person's communication behavior. That influence arises through a process of perception and the meaning of reality.

\section{DISCUSSION AND CONCLUSION}

The promotions implementation carried out by the Culture and Tourism Department at the Open Pit Nam Salu Geosit tourist attraction is done through 3 kinds of activities, namely advertising, personal selling, and public relations activities. Advertising used by the Culture and Tourism Department of East Belitung Regency on the Open Pit Nam Salu Geosit tourist attraction is to attract tourist visits. The advertising used is by using online media and print media. The online media is the main choice of the Culture and Tourism Department of East Belitung Regency in promoting Open Pit Nam Salu Geosit. Virtual media was chosen for conveying information or advertising that can reach a wider audience. Therefore, promotion through online media is cheaper. The media most often used by the Culture and Tourism Department of East Belitung Regency in promoting Open Pit Nam Tourism Objects Salu Geosit are the online media website.

Moreover, personal selling is an oral presentation to several prospective buyers to create a sale. Personal selling is made by meeting face-to-face with consumers. The interaction between sellers and consumers becomes better for consumer references to the products sold for higher profit. Besides, holding the Table Top event is another face-to-face selling carried out by the Culture and Tourism Department of East Belitung Regency on the Open Pit Nam Salu Geosit tourist attraction. The Table Top is an event designed to bring together the regional tourism industry players with other regional industry players. Lastly, another promotion implementation carried out by the Culture and Tourism Department of East Belitung Regency is public relations activities. Public Relations plays an essential role in growing good relations between all institution components to motivate mutual understanding and participation to foster good relations with the public and gain a favorable public opinion.

\section{ACKNOWLEDGEMENT}

This research was completed with the help and support of various parties, for that the researchers would like to express their gratitude and highest appreciation to the honorable:

1. We thank the Rector of Unikom, Prof. Dr. H. Eddy Soeryanto Soegoto, MT., for the support and funds provided for the implementation of the seminar and the process of publishing this article.

2. The Dean of FISIP Unikom and the head of the Communication Studies program have provided support for implementing the research carried out.

3. Director of Journal and Scientific Works of UNIKOM, Dr. Poni Sukaesih, S.Ip., M.Si and 
all the Icobest 2021 Committees who have worked hard and are highly committed to the preparation and implementation of the UNIKOM International Seminar

4. Key informant Mrs. Eviliah, SE, as Head of the Marketing and Tourism Office, Mr. Iphan Oktoriady, as Head of the Marketing Section of the Culture and Tourism Office of East Belitung Regency who has helped provide the information needed by researchers in completing the research.

5. Supporting informants who help provide the information needed to complete the research and the entire research team to share their knowledge.

\section{REFERENCES}

Ajeng Fitri N. (2016). Penelitian ini memiliki beberapa tujuan, pertama untuk mengetahui pengaruh daya tarik wisata terhadap kepuasan wisatawan, tujuan kedua untuk mengetahui pengaruh kepuasan wisatawan terhadap niat kunjungan ulang dan tujuan yang ketiga untuk mengetahui pen. (2), 1-9.

Speirs, A. 2010 Yogyakarta Kompas.com

Aliyah, K. A. (2017). Pengaruh promosi melalui media sosial terhadap keputusan pembelian dengan viral marketing sebagai variabe intervening

Ardianto, E. (2010). Metode Penelitian Public Relations. Kuantitatid Dan Kualitatif. Bandung: Simbiosa Rekatama

Basiya, R., Abdul, H., \& Rozak, A. (2012). Kualitas dayatarik wisata, kepuasan dan niat kunjungan kembali wisatawan mancanegara di jawa tengah. Dinamika Kepariwisataan, 2(XI), 1-12.

Diniyah, F. (2019). Pengaruh Daya Tarik Wisata Terhadap Minat Kunjungan Ulang Wisatawan (Studi di Museum Benteng Vredeburg Yogyakarta).

Evilliah, Wawancara 5 juli 2021, pukul 13.00 WIB

Hendrawathy, I Dewa Ayu, Eksistensi Dramawisata dalam Pemulihan Kepariwisataan Bali Pasca Krisis (Suatu Tinjauan Fenomenologys Komunikasi), Jurnal Kajian Ilmu Komunikasi Fakultas Ilmu
Komunikasi Universitas Dwijendra Denpasar, Vol.2, No, 1, Hal 51-64, ISSN: 1907-5413

Wartaeven. (2021). https://wartaevent.com/promosi-budayaindonesia-lewat-media-digital/, Wartaeven.com. Kabupaten Blitar, Wednesday, October 20, 2021, pukul 05.15 WIB

Oktoriady, I. (2021). Wawancara, Kamis 25 maret 2021, pukul 11.30 WIB dan Senin 5 Juli 2021, Pukul 15,30 WIB

Werthi, K. T. (2021). Dosen STMIK Primakara sekaligus Relawan TIK Bali, saat menjadi pembicara dalam Webinar Gerakan Nasional Literasi Digital 2021 untuk wilayah Kabupaten Blitar, Jawa Timur.

Sudana, I. P. (2013). Strategi Pengembangan Desa Wisata Ekologis di Desa Belimbing, Kecamatan Pupuan Kabupaten Tabanan. Analisis Pariwisata, 13(1), 11-31.

Sugiyono. (2017). Metode Penelitian Kuantitatif, Kualitatif, dan R\&D. Bandung: Alfabeta

Tjipno, F. (2008). Strategi pemasaran. Penerbit Andi.

Yoety, O. A. (2006). Komersialisasi seni budaya dalam pariwisata. Angkasa, 1985.

Fanny, Y. (2017). Pengaruh Daya Tarik Wisata Terhadap Keputusan Berkunjung Ke Objek Wisata Alahan Panjang Resort Danau Diatas Kabupaten Solok. (September).

\section{ABOUT THE AUTHORS}

Desayu Eka Surya, email: desayuekas1012@email.unikom.ac.id

Desayu Eka Surya, Communication Science Program, Faculty of Social and Political Sciences, Universitas Komputer Indonesia, Bandung, Indonesia.

Beni Efrianto, Communication Science Program, Faculty of Social and Political Sciences, Universitas Komputer Indonesia, Bandung, Indonesia. 